\author{
Artur Żywiołek \\ Uniwersytet Humanistyczno-Przyrodniczy im. Jana Długosza w Częstochowie \\ ORCID: 0000-0002-6904-5608
}

\title{
Intelektualista jako upadły prorok. Dyskretny, retoryczny urok Syrakuz
}

Wedle tradycyjnej, ale i obiegowej opinii retoryka należy do dziedziny wiedzy, której uprawomocnieniem zajmuje się sztuka perswazji wyposażona w określone reguły i językowe sposoby artykulacji. Z kolei retoryczność odnosi się do pewnej właściwości języka i jako taka może ulegać rozmaitym przekształceniom, zwłaszcza zaś wyemancypowania spod wpływu filozofii „fundamentalistycznej” czy systemowej:

Między retoryką a retorycznością zachodzą dość skomplikowane relacje. Nie jest to prosta opozycja (która na przykład poddawałaby się dialektycznej syntezie), lecz związek oparty na nieustannym wzajemnym podważaniu autorytetu drugiej strony. Nieustannym - gdyż obie strony istnieją za cenę wzajemnej koegzystencji: ani retoryka nie może pozbyć się (ze swojego dyskursu) retoryczności, ani też retoryczność nie może zaistnieć bez (metajęzyka) retoryki.

(Rusinek, 2003: 10)

Nie wdając się w szczegółowe analizy i prezentacje owej kolizji retoryki i retoryczności, warto zauważyć, że także w obszarze wyznaczonym przez klasyczną retorykę trudno mówić o jedności i braku zróżnicowania. Według Arystotelesa retoryka obejmuje trzy podstawowe dziedziny: ethos, pathos i logos

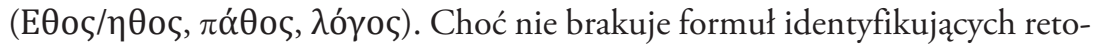
rykę ze sferą logosu (umysłu, języka, argumentacji), czego przykładem może 
być Imperium retoryki Chaima Perelmana (2002), to jednak podobnie jak w przypadku retoryczności, która „nie może zaistnieć bez metajęzyka retoryki, tak i sama retoryka nie może de facto istnieć w oderwaniu od etosu nadawcy i patosu audytorium (odbiorców). Dialektyczny splot ethosu, pathosu i logosu przyczynił się ongiś do uprawomocnienia „mocnych” koncepcji teoretycznoliterackich, takich jak strukturalizm czy fenomenologia; koncepcji dostarczających „rozkosznej” pewności i satysfakcji poznawczej. Oczekiwania rozmaitych audytoriów (środowisk czytelniczych, naukowych stowarzyszeń, instytucji itp.), pragnienie posiadania wiedzy pewnej, ścisłej i konkluzywnej spełniał i gwarantował sam uczony theoros, intelektualista, zajmujący ważną pozycję w symbolicznej przestrzeni (symbolicznym polu, by posłużyć się określeniem Pierre’a Bourdieu) wyznaczonej przez instytucję (i ideę) uniwersytetu, rozumianego niegdyś jako społeczność zaangażowana w poszukiwanie prawdy i żyjąca bardziej „dla idei” niż „z idei”. Współcześnie uczony-theoros, świecki kapłan, „prawodawca”, ustąpił miejsca „tłumaczowi”, „interpretatorowi” (Bauman, 1998), badaczowi, ekspertowi (profesjonaliście) współpracującemu z otoczeniem społeczno-gospodarczym i działającemu podług reguł określonych przez odpowiednie ministerialne instancje, tudzież inne wpływowe instytucje i towarzystwa. Perswazyjna moc wielkich teorii („wielkich narracji naukowych”) uległa radykalnemu osłabieniu, do czego przyczynił się nie tylko rozpad teoretycznego logosu - wywołany między innymi afektywnym oddziaływaniem nudy, niechęci, wstrętu i wielu innych czynników opisanych przez Arystotelesa w drugiej księdze Retoryki - lecz także, i przede wszystkim, zmianami w zakresie ethosu naukowca i specyfiki patosu jako afektywnego uwarunkowania audytorium. To nie są, rzecz jasna, jedyne i wyłączne przyczyny entropii „wielkich teorii”, zawsze niewspółmiernych wobec skomplikowanej rzeczywistości, zwłaszcza wobec literatury, tego „najbardziej niepewnego gruntu”, wedle słów Stanisława Lema. Nie sposób wszak zaprzeczyć, że przekształcenia zachodzące w sferze ethosu i pathosu mogły odegrać kluczową rolę w kształtowaniu się nowych konstelacji teorii i teoretyków literatury/kultury i destrukcji dawnych, tradycyjnych ujęć. Już fragmentaryczny przegląd stanowisk z ostatnich kilkudziesięciu lat w kwestii sposobów uprawomocnienia teorii i wiedzy naukowej, albo „wiedz”, jak pisze Peter Burke, podkreślając „mnogość” rozmaitych form wiedzy/nauki (Burke, 2016), pozwala dostrzec, jak ważnym elementem w postawaniu nowych 
i śmierci starych kosmosów teorii jest „ucieleśniony” i poddany presji afektów rozum (logos), ethos uczonego i oczekiwania różnych audytoriów i gremiów (przede wszystkim ekonomicznych), których zjednywanie życzliwości i akceptacji (captatio benevolentiae) stanie się podstawową strategią komunikacyjną, zastępującą dawny zwyczaj dążenia do prawdy, respektowania cnoty i kształtowania szlachetności charakteru. Jak jednak pisze Jean-François Lyotard, „ponowoczesnej kondycji obce jest [...] zarówno rozczarowanie brakiem uprawomocnienia [wiedzy], jak i ślepa jego akceptacja” (Lyotard: 21). Relacja między pozycją nadawcy (informacji, wiedzy) a odbiorcą, tudzież gry językowe, które niejako samoczynnie uruchamiają się przy tej okazji, każą autorowi Kondycji ponowoczesnej postawić fundamentalne pytanie:

Badając aktualny status wiedzy naukowej, stwierdzamy, że wtedy właśnie, kiedy wydaje się ona bardziej niż kiedykolwiek podporządkowana siłom politycznym i kiedy wraz z pojawieniem się nowych technologii grozi jej nawet, że stanie się jedną z głównych stawek konfliktu między nimi, problem podwójnego uprawomocnienia, zamiast ulegać zatuszowaniu, musi stanąć z tym większą ostrością. Staje bowiem w swej najpełniejszej formie, formie wzajemnej odwracalności, ujawniającej, że wiedza i władza to dwa oblicza tego samego pytania: kto decyduje o tym, co to jest wiedza i kto wie, jak należy decydować? Problem wiedzy w epoce informatycznej jest bardziej niż kiedykolwiek problemem zarządzania.

(Lyotard: 39)

Pisząc te słowa u schyłku lat siedemdziesiątych minionego stulecia, Lyotard miał, oczywiście, nieadekwatne wyobrażenia o dzisiejszej perswazyjnej mocy mediów. Jednak nie w tym tkwi istota problemu. Autor Kondycji ponowoczesnej trafnie, jak się zdaje, lokalizuje źródło uprawomocnienia wiedzy. Wiedzy, a więc także każdej naukowej teorii nie legitymizują agoniczne i zmienne „gry językowe”, lecz komunikacyjne porozumienie, milcząca zgoda między nadawcą a odbiorcą. Reguły gier językowych, pisze Lyotard, „nie zawierają swego uprawomocnienia w samych sobie, lecz [...] stanowią przedmiot wyraźnej, bądź milczącej umowy między grającymi (co nie musi oznaczać, że to oni ją wymyślaja)" (Lyotard: 44).

Posługując się terminologią Arystotelesowskiej Retoryki, można by stwierdzić, że o prawomocności teorii decyduje akceptacja i aprobata ethosu i autorytetu naukowca/badacza przez stosowne audytorium. Ważną rolę odgrywają 
także afekty. Wszak nie zawsze prowadzi się grę po to, by wygrać, twierdzi Lyotard, lecz dla przyjemności, jaką daje sama gra (Lyotard: 45). To zjawisko wyjaśnia również w pewnym sensie przyczyny, dla których naukowcy okresowo odczuwają silną potrzebę (żądzę?) wymiany dotychczasowych metadyskursów badawczych; potrzebę motywowaną nudą, zniechęceniem, a nawet wstrętem czy obrzydzeniem.

Kim zatem jest i jaką pozycję zajmuje w nowoczesnym społeczeństwie (Gemeinschaft?, Gesellschaft? Geselligkeit?) uczony uczestnik (theoros) uroczystej "gry w teorię”? „Rozpad wielkich narracji” skutkował, jak przekonuje Lyotard, „rozpuszczeniem się więzi społecznych i przejściem od społecznych zbiorowości do stanu masy złożonej z indywidualnych atomów wprawianych w absurdalne ruchy Browna” (Lyotard: 59). Także uczony, profesor, intelektualista bezpowrotnie utracił swój uprzywilejowany status w społeczeństwie wyobrażonym pod postacią systemu czy organizmu. Rozpadowi uległy mity, podania i baśnie sakralizujące i sankcjonujące pozycję owego niegdysiejszego kapłana, prawodawcy, proroka, który dziś jest, co najwyżej, ekspertem czy profesjonalistą, a najpewniej małym elementem w korpo-uniwersytecie wytwarzającym produkty użyteczne dla społeczeństwa globalnej konsumpcji. „Profesor, jak pisze autor Kondycji ponowoczesnej, nie jest [...] bardziej kompetentny od komputerowych zasobów pamięci, by przekazać ustaloną wiedzę i nie jest bardziej kompetentny od interdyscyplinarnych zespołów, by wymyślać nowe posunięcia i nowe gry" (Lyotard: 148).

W tym miejscu mogłaby się rozpocząć neverending story na temat mądrych i głupich intelektualistów, na temat prawdziwych myślicieli, uczonych, ale i fałszywych proroków wytwarzających modny bełkot, przed którym klękają w niemym zachwycie mieszkańcy nie tylko uniwersyteckich kosmosów/uniwersów. Nie sposób, rzecz jasna, zaprzeczyć, że w minionym stuleciu powstało wiele wybitnych rozpraw i dzieł odznaczających się poważnym traktowaniem literatury i kultury. Nie sposób również wykluczyć, że także wiek XXI przyniesie imponujące teorie kultury, być może motywowane powrotem do źródeł naukowej humanistyki (semiotyka, fenomenologia, egzegeza). Nie można jednak wziąć w nawias bezliku głupstw czy też przejawów bezmyślności nowoczesnych intelektualistów pretendujących do roli proroków i przewodników, zapominając o ich destrukcyjnym oddziaływaniu na myślenie o literaturze. Wielość publikacji 
poświęconych ethosowi (niekiedy anty-etosowi) współczesnego, „strąconego z niebios" intelektualisty nie pozwala wyczerpująco zrekonstruować wszystkich możliwych stanowisk i ujęć, choć, niewątpliwie, taka rekonstrukcja byłaby zapewne pożyteczna. $Z$ drugiej wszelako strony warto pamiętać o przestrodze Marka Lilli, wedle którego „ktokolwiek weźmie na siebie ciężar napisania uczciwej intelektualnej historii dwudziestowiecznej Europy, będzie musiał mieć żelazne nerwy" (Lilla: 162). Spełnienie afektywnego warunku, na który wskazuje autor Lekkomyślnego umystu („mieć żelazne nerwy”), wynika z faktu istnienia długiej listy błędów, jakie popełnili intelektualiści w dziejach nowoczesnej Europy. Można więc postawić hipotetyczne pytania: czy i w jakim stopniu do rozkładu naukowych, „,mocnych” teorii literatury/kultury przyczynił się - oprócz kryzysu „oświeceniowego” logosu, rozumu teoretycznego - upadek autorytetu (ethosu) uczonego (intelektualisty) oraz niestabilna sytuacja audytorium?

Źródła „oświeceniowego” logosu mają charakter afektywny:

Oświecenie rozumiane najszerzej jako postęp myśli - zawsze dążyło do tego, by uwolnić człowieka od strachu i uczynić go panem. Lecz oto w pełni oświecona ziemia stoi pod znakiem triumfującego nieszczęścia. Programem oświecenia było odczarowanie świata. Chciano rozbić mity i obalić urojenia za pomocą wiedzy.

(Adorno, Horkheimer: 15)

W tej krótkiej wypowiedzi zawarte są ważne informacje. Po pierwsze, „postęp myśli” zakłada wolność człowieka od lęku, po drugie zaś - panowanie, pragnienie/żądzę władzy. Konsekwencją oświecenia jest natomiast „tryumfujące nieszczęście”, polegające na odczarowaniu świata za pomocą wiedzy. W podobnym tonie wypowiedział się dużo wcześniej Hegel. Rozpadowi dotychczasowego świata (określanego mianem „noc świata”, Weltnacht), przejściu od jednej formacji kulturowej do drugiej jak cień towarzyszy „lekkomyślność” i „nuda”:

[...] duch kształtujący się w nową postać dojrzewa powoli i cicho, rozkłada cząstka po cząstce gmach swego poprzedniego świata, a na jego chwianie się wskazują tylko pojedyncze symptomy; lekkomyślność i nuda [podkr. A.Ż], które nadszarpują istniejącą rzeczywistość, nieokreślone przeczucia[podkr. A.Ż] nieznanego zwiastują, że nadciąga coś innego. Stopniowe rozkruszanie, które [przez długi czas] nie zmieniło fizjonomii całości, zostaje [nagle] przerwane przez wschód, ukazujący od razu, jak błyskawica, postać [das Gebilde] nowego świata. 
W Zniewolonym umyśle Czesław Miłosz, a za nim także Mark Lilla oraz Raymond Aron trafnie, jak się zdaje, zarejestrowali afektywne oznaki nowej rzeczywistości i nowej sytuacji intelektualistów wraz z ich lekkomyślnym pragnieniem władzy i wiarą w możliwość zbudowania nowego porządku rzeczywistości. Omawiając sylwetki czterech polskich pisarzy/intelektualistów, Miłosz analizuje nie tylko ich „heglowskie ukąszenie”, lecz także - i przede wszystkim - ich namiętności („rozkosze Ketmanu”) jako główne czynniki przystosowania się intelektualistów do komunistycznej nowej wiary („utopii w działaniu”, mówiąc za Baumanem). Centralnym problemem pozostaje jednak „zwiedziony/zniewolony/zniewalający” umysł, jak można by przetłumaczyć określenie captive mind; określenie umysłu (logosu), który poddaje się zniewalającemu urokowi rozmaitych politycznych opiów, quasi-religijnych przeżyć współczesnych intelektualistów. Z kolei Mark Lilla zatytułował swoją, będącą niewątpliwą kontynuacją Miłoszowych rozpoznań, książkę The Reckless Mind. „Lekkomyślny” - ale także „ryzykowny”, „brawurowy”, „,nieopatrzny”, „wiodący na oślep” - umysł to formuła, która stoi w jaskrawej sprzeczności z deklarowaną czy proklamowaną pozycją intelektualisty, nie mającej żadnej, poza nią samym, historycznej legitymacji (uprawomocnienia) swojego statusu:

Od inteligencji nie wymaga się niczego innego jak tylko tego, by określiła się jako inteligencja. Uczyniwszy to, inteligenci uważali, że kwalifikują się do rządzenia. Jeśli na drodze do osiągnięcia tego celu pojawiają się przeszkody, to są to przeszkody stwarzane przez ludzi bezmyślnych, przez „burżuazję”, i mogą być usunięte bez wyrzutów sumienia.

(Scruton, 2006: 165)

Ten brak wyraźnie określonego statusu społecznego, tudzież brak społecznej legitymizacji jest jedną z przyczyn, dla których intelektualiści uzurpują sobie prawo do orzekania w kwestiach dotyczących polityki, polityczności, światopoglądu, ideologii, etyki, prawa, religii itd. Poczucie wyższości, elitaryzm, merytokratyzm, pycha (superbia) wynikają z przekonania o posiadaniu wiedzy specjalistycznej, niedostępnej „nieoświeconej gawiedzi” (profanum vulgus), którą to gawiedzią „oświeceni” intelektualiści gardzą.

Pisze o tym Thomas Sowell:

Wielu intelektualistom $\mathrm{i}$ ich sympatykom nadmiernie imponuje fakt, że wykształcone elity, do których się zaliczają, posiadają o wiele więcej wiedzy per capita 
(tzn. wiedzy specjalnej) niż ogół populacji. Stąd już tylko krok do mianowania wykształconych elit arbitrami tego, co w społeczeństwie powinno się robić, a czego nie powinno. Często ich uwadze umyka jednak pewien istotny fakt. Mianowicie to, że zwykli ludzie, jako ogół, mogą dysponować o wiele większą pulą wiedzy (tej wiedzy przyziemnej) niż elity - nawet jeśli ich wiedza jest pokawałkowana i rozproszona wśród ogromnej liczby ludzi, z których każdy posiada ułamek tej ogólnej wiedzy, w mało efektownej postaci.

(Somwell, 2010: 34)

Egzemplarycznych dowodów na to, że posiadanie wiedzy specjalistycznej oraz wyrafinowanych kompetencji intelektualnych nie zabezpiecza uczonego, myśliciela czy badacza przed moralną i poznawczą klęską, jest bardzo wiele. Może nawet zbyt wiele. Zwrot Martina Heideggera w stronę faszyzmu i nazizmu, fascynacja Sartre’a komunizmem, wiernopoddańcze gesty polskich pisarzy wobec stalinizmu, uzasadnienie terroru w imię przyszłej sprawiedliwości społecznej (jak to uczynił Merleau-Ponty w rozprawie Humanizm i terror), ludobójstwo Pol Pota, absolwenta prestiżowej École des Technologies de L'informatique et du Management - wszystko to i wiele innych zdarzeń i postaw składa się na obraz intelektualisty-fałszywego proroka zaprzedanego demoniczno-faustycznym mocom. W dwudziestym stuleciu „myśliciele nowej lewicy” czynnie zaangażowali się w walkę przeciwko dotychczasowemu porządkowi społecznemu, uzasadniając swoje działania ideą walki o równość i emancypację. Pisze o tym między innymi Roger Scruton w książce Gtupcy, oszuści i podżegacze (Scruton, 2018). Brytyjski konserwatysta poddał ironicznej analizie liczne teksty i deklaracje intelektualistów określanych mianem thinkers of the left. W naszych czasach ethos uczonego, myśliciela, badacza, eksperta, profesjonalisty, teoretyka związał się na trwałe (?) z pakietem opinii (mniemań, poglądów) o braku obiektywnej prawdy, nieobecności znaczenia w tekście, względności aktów interpretacji, quasi-mesjańskimi postulatami o wyzwoleniu społecznym spod opresywnej władzy religii, rodziny, szkoły (uniwersytetu). Atak Scrutona na intelektualną lewicę (podobno pojęcie „prawicowy intelektualista” to oksymoron) znamionuje czysta negatywność (Scruton, 2018: 402). Czy jednak ideologia "of the left" niesie jakiś pozytywny program czy tylko rewolucyjną de facto wizję socjalizmu jako „utopii w działaniu” (Bauman, 2010)? 
Krytyka ze strony myślicieli lewicowych bardzo często zaczyna się od potępienia naszych systemów politycznych i socjalnych. Pierwszym obiektem ataku jest język i jest to część ich długoterminowej strategii, polegającej na umieszczeniu władzy i dominacji na szczycie agendy politycznej. Lewicowa nowomowa to bardzo skuteczne narzędzie - nie tylko zrównuje z ziemią cały nasz świat społeczny, lecz także sugeruje, że składa się on ze zwodniczych pozorów, za którymi kryje się prawdziwa rzeczywistość. „Siły materialne”, „antagonistyczne relacje produkcji”, „nadbudowa ideologiczna” Marksa; rządzące „episteme” i „struktury dominacji” Foucaulta; „wymuszanie”, „zbiory generyczne” oraz „procedury prawdy” Badiou, wielki Inny Lacana i Žižka, „urzeczowienie” oraz „fetyszyzm towarowy” Lukácsa - wszystkie te tajemnicze technikalia mają na celu zawłaszczenie rzeczywistości i wyrwanie jej z naszego świata społecznego poza polityczny nawias. Mamy uwierzyć, że jedynym sposobem na rozwiązanie naszych konfliktów jest totalna transformacja, totalna rewolucja lub, jak określił to Profesor, postać w powieści Tajny agent Josepha Conrada, „zniszczenie wszystkiego, co jest”.

(Scruton, 2018: 402-403)

Lewicowy etos tworzą, zdaniem Scrutona, namiętności polityczne, wśród których na pierwszy plan wysuwa się ,atak na język” jako dziedzinę mistyfikującą „prawdziwą” rzeczywistość. Krytyka języka, to jest narzędzia „fałszywej świadomości”, staje się podstawowym warunkiem przyszłej rewolucyjnej odmiany, „totalnej transformacji”. Scruton zwraca także uwagę na pewien specyficzny paradoks. Oto bowiem rewolucyjny akt „wyrwania” rzeczywistości poza „polityczny nawias" okazuje się de facto gestem ponownego upolitycznienia, a to z kolei prowadzi do „pretensji wszystkich współczesnych ideologii politycznych - wedle słów Julesa Bendy - do ugruntowania się w nauce, do bycia rezultatem "ścisłej obserwacji faktów «” (Benda: 122). Omawiając to „roszczenie”, autor Zdrady klerków napisat:

[...] namiętności polityczne wykazują w naszych czasach nieznany dotąd stopień uniwersalności, spójności, homogeniczności, precyzji, ciaggłości i przewagi wobec innych pasji. Uzyskują niespotykaną wcześniej samoświadomość. Niektóre z nich, do których dotąd rzadko się przyznawano, budzą się do świadomości i dołączają do tych dawniejszych. Inne bardziej niż kiedykolwiek uwalniają się od wszystkiego, co nie jest czystą namiętnością, opętują kiedyś dla nich nieosiągalne moralne regiony ludzkich serc, nabierają niespotykanego od wieków mistycznego charakteru. W końcu wszystkie uzbrajają się w ideologiczne narzędzia, które pozwalają im głosić w imię nauki naczelną wartość własnych działań i swoją historyczną konieczność. Zarówno na powierzchni, jak i w głębi, w wymiarach przestrzennych 
i w wewnętrznej sile, namiętności polityczne osiągają dziś nieznaną dotychczas doskonałość. Dzisiejszy wiek jest w swej istocie wiekiem polityki.

(Benda: 122)

Oto kolejny paradoks. Z jednej strony współczesne ideologie roszczą sobie prawa do naukowości, z drugiej zaś ta perswazyjna moc naukowości znajduje swoje ugruntowanie w politycznych namiętnościach. Bez względu na to, czy głosi się prymat jednej prawdy, czy też, przeciwnie, względność prawdy, naczelną (niekiedy nieuświadomioną) motywacją nauki jest polityczność, namiętność, opętanie „ludzkich serc”. Dochodzą do tego także inne czynniki, takie jak urynkowienie usług intelektualnych, instytucjonalne regulacje, rosnący wpływ mediów i uchodzące za obiektywne przekonanie o konieczności współpracy z otoczeniem gospodarczym. Uniwersytety przestały być miejscem wolnego od zewnętrznych zacisków poszukiwania prawdy. Zamiast tego dominujący wpływ na zmianę klimatu intelektualnego miało „akademickie karierowiczostwo”, odpowiedzialne za „drenaż mózgów i osłabienie życia umysłowego” (Furedi: 39).

Autor tej ostatniej opinii, Frank Furedi, wszystkie te zmiany obejmuje formułą „konfrontacji z dwudziestopierwszowiecznym filisterstwem”, jak to wyraża angielski tytuł przywołanej książki (Where have all the intellectuals gone. Confronting 21st century philistinism). Zdaniem Furediego intelektualista to mieszkaniec „kraju filistrów” - kraju, który charakteryzuje powstawanie „wiedzy bez znaczenia”, „kwestionowanie wiedzy”, „kult banalności”, dewaluacja standardów naukowych i intelektu, „błahe dążenia”, wreszcie zaś swoista parodia retorycznej strategii captatio benevolentiae, nazywanej przez Furediego „kulturą schlebiania” masowym gustom, co z kolei zostało już zdiagnozowane wiele lat wcześniej w słynnej książce Bunt mas Ortegi y Gasseta. Zgoda co do tego, że wysokie wymagania intelektualne stawiane jeszcze do niedawna świadczeniobiorcom usług edukacyjnych powinny ustąpić powszechnemu dostępowi do przedsięwzięć edukacyjnych czy kulturowych, sprawiła, że takie instytucje, jak uniwersytety czy muzea stały się dzisiaj raczej „parkami rozrywki” (Furedi: 105), niż „fundamentem, na którym mogłoby rozwinać się życie intelektualne” (124). Ta nowa „inżynieria społeczna” powoduje powszechną infantylizację:

Infantylizację kultury najwyraźniej widać w wynoszeniu na piedestał osobistego doświadczenia. Kiedy edukację i kulturę traktuje się jako projekcję indywidualnych odczuć, idee i dzieła sztuki zaczyna się cenić raczej ze względu na to, jakie znaczenie 
mają dla jednostek, niż ze względu na ich doniosłość i wagę dla społeczności. Kultura, która istnieje po to, żeby pomóc ludziom odnaleźć siebie, sprzyja klimatowi obsesji na własnym punkcie i introwertyzmowi. [...] Kultywowanie podobnego nastawienia w społeczeństwie jest oznaką infantylizacji. Głos przeciętności, który mówi: „to moja historia”, wcale nie odbiega daleko od nabrzmiałego emocjami okrzyku: „to moja zabawka”.

(Furedi: 129-130)

Warto podkreślić, że Frank Furedi opiera swoje opinie na bezpośredniej obserwacji studentów i wykładowców renomowanych uczelni (Harvard, Oxford), a nie lokalnych uniwersytetów, na które nakłada się obowiązek doganiania świata, który wciąż nam się oddala. Brytyjski socjolog poddaje krytyce te zachowania wykładowców i studentów, które już od dawna funkcjonują jako zbiór elementarnych oczywistości: „protekcjonalny stosunek do studentów”, „styl rodzicielskiej afirmacji”, „przedstawianie jasno określonych celów nauki”, unikanie wszelkich zachowań mogących „zranić uczucia studentów”. Wszystko to, zdaniem Franka Furediego, oznacza nie tylko daleko posuniętą infantylizację, lecz jest także efektem „pesymistycznego i antydemokratycznego stosunku do ludzi” (Furedi: 132). W ten oto sposób

[...] brak uznania dla autorytetu elity prowadzi do sytuacji, w której elicie trudno jest się przekonać o własnej misji. Ponieważ nie ma żadnych silnych przekonań, jest otwarta na negocjacje na temat tego, co należy cenić, a co odrzucić.

(Furedi: 135)

Arystotelesowski trójpodział retoryki (logos, ethos, pathos) poddany został działaniu sił rozkładowych, zwłaszcza w dziedzinie autorytetu uczonego oraz stanu i pozycji audytorium. Brak wiary w autorytet elity, schlebianie pospolitym gustom i oczekiwaniom, nadto jeszcze, uznawana za zjawisko naturalne, „inżynieria społeczna” prowadzi, wedle Furediego, do powstania uległego, konformistycznego i konsumpcyjnie nastawionego społeczeństwa. Konsekwencje takiego stanu rzeczy są groźne: rozpad wielkich narracji/teorii, niezdolność do sprostania wyzwaniom współczesności, radykalna nieumiejętność „myślenia inaczej" (think different). Konkluzja Franka Furediego jest w równym stopniu pesymistyczna, co postulująca swoiste „wyjście z niedojrzałości”, jak to proklamował ongiś Immanuel Kant: 
Proces równania w dół, jeśli to pojęcie cokolwiek znaczy, nie odnosi się do ludzkiej inteligencji, tylko do kultury, a dokładniej - do elit, które regulują przepływ idei. Niewiele możemy zrobić, żeby zmusić elity, by zarzuciły swój instrumentalistyczny i filisterski pogląd na świat. Możemy jednak stoczyć bitwę o idee w sercach i umysłach ludzi. Jak to zrobić - oto fundamentalne pytanie naszych czasów.

(Furedi: 141)

Ostatnie zdanie przytoczonego tekstu pobrzmiewa, bądź co bądź, naiwnością, niemniej jednak „uwiarygodnienie relatywistycznych epistemologii” przez współczesnego homo academicus każe postawić pytanie o status farmakologii wiedzy/głupoty; rolę farmakonu, który byłby nie tylko trucizną, lecz także autentycznym lekarstwem na rozpad akademickiego etosu.

Próbę taką podjął uczeń Jacquesa Derridy, Bernard Stiegler, w książce Wstrzasy. Gtupota i wiedza wXXI wieku. Stiegler zajmuje pozycję zgoła odmienną od uprzednio przedstawionych. Kryzys uniwersytetu jako miejsca powstawania tyleż wiedzy, co głupoty, infantylizację studentów, rozpad autorytetu profesorów autor Wstrząsów próbuje przemyśleć na nowo dzięki powtórnej lekturze i reinterpretacji takich dzieł, jak Spór fakultetów Kanta, Dialektyka oświecenia Adorna i Horkeimera, Doktryna szoku Naomi Klein, Fenomenologia ducha Hegla, a także pism Marksa, Derridy, Deleuze’a. Stieglera odróżnia jednak od takich myślicieli, jak Lilla, Aron, Scruton, Sowell, Furedi to, że próbuje on dać odpowiedź na fundamentalne pytanie: co i jak zrobić, aby wygrać bitwę o przyszłość intelektualistów wiedzy i uniwersytetu?

Podstawową kwestią jest dla Bernarda Stieglera adekwatne rozpoznanie sytuacji, w jakiej znalazł się ponowoczesny intelektualista; a jest to sytuacja dokonanej katastrofy, wstrząsu właśnie, wywołanego przez kryzys ekonomiczny roku 2008; kryzys będący konsekwencją długotrwałego zapomnienia tego, że wolnorynkowe gry w zglobalizowanym i turbokapitalistycznym świecie popędowej (libidalnej) ekonomii nie są elementem naturalnego porządku rzeczywistości, lecz stanowią efekt znaturalizowanej teoekonomicznej mitologii/ ideologii spod znaku Bogactwa narodów Adama Smitha, co trafnie rozpoznał i opisał w Wielkiej Transformacji Karl Polanyi. Idea wolnego rynku - jako przestrzeni, w której działają zapomniane i wyparte libidalne afekty (chciwość, żądza bogactwa i władzy), przedstawiane następnie jako zalgorytmizowane procesy kierujące w sposób rzekomo racjonalny działaniami ekonomicznych 
podmiotów - doprowadziła, zdaniem nie tylko Stieglera, do degradacji wspólnot społecznych, zastępując je sztucznymi tworami typu Gesellschaft czy nawet Geselligkeit, jak to określa Georg Simmel (2012) ${ }^{1}$.

To właśnie profesorowie ekonomii, hegemoniczni intelektualiści i „prorocy” naszych czasów są odpowiedzialni za to katastrofalne w skutkach zapomnienie o afektywnym (libidalnym) charakterze procesów ekonomicznych, czego skutkiem stała się proletaryzacja rozumu „odzianego w łachmany racjonalizacji”, deindywiduacja jednostki ludzkiej oraz likwidacja „wszystkich form wiedzy” i „umiejętności teoretycznych”:

Ów proces jest procesem gramatyzacji - w którym proletaryzacja myślenia i pojętności, wymykającej się w ten sposób rozumowi, czyli „panowaniu celów” (a zarazem temu, co zasadniczo oznacza racjonalizacja opisana przez Webera), jest tym, co - mimo że rozwija pewien rodzaj pragmatycznej inteligencji, mikstury [métis] zmyślności i pomysłowości, za sprawą których wydaje się, że każdy staje się sprytniejszy [malin] - prowadzi do powszechnego otępienia [abêtissement], które daje o sobie znać w 1944 roku wraz z jeszcze wówczas świeżym nadejściem przemysłów kultury: „Zamieniony w dobro kultury i serwowany dla celów konsumpcyjnych [duch] musi zginąć. Zalew dokładnych informacji i galanteryjnej rozrywki zaostrza dowcip i zarazem otępia”. Regres tworzy w ten sposób koktajl zmyślnych głupot wywodzących się z kulturowego konsumpcjonizmu, natomiast głupota, ogólnie rzecz biorąc, jest wyrazem pragnienia. Regres tego jest niczym innym jak powrotem do jego pierwotnego stadium, jakim jest popęd.

(Stiegler: 124-125)

Proces, o którym mówi Stiegler, nie dotyczy wyłącznie naszych czasów. Regres rozumu w nierozum (bezmyślność, głupotę, szaleństwo) stanowi cechę każdej generacji i każdego aktu teoretyzowania, skoro wiedza teoretyczna „przytrafia się ulegającej regresji duszy noetycznej [...] w nieregularnych nawrotach” (Stiegler: 125). Z kolei rolę instytucji akademickich, a zwłaszcza uniwersytetu, autor Wstrząsów wywodzi także, przynajmniej w części, z mroku niewiedzy. To, co zwie się myśleniem - przekonuje Stiegler - powinno przyczyniać się do „szkodzenia głupocie”, natomiast profesorowie („istoty rozumne”, wedle określenia Stieglera) powinni formować owe instytucje wedle rozumnych regut:

${ }^{1}$ Stiegler, ilustrując swoje rozważania, odwołuje się do filmu Inside Job, będącego „anatomią kryzysu" z 2008 roku. 
Jednak w to, że tak jest, powątpiewają coraz częściej nie tylko uczniowie i studenci tychże nauczycieli i profesorów; powątpiewają w to nie tylko rodzice tychże uczniów i studentów, podając w wątpliwość, czy uczący ich dzieci nauczyciel i profesorowie rzeczywiście są rozumni w kacie. Pełni wątpliwości są bowiem i przede wszystkim sami profesorowie - mam tutaj na myśli zwłaszcza profesorów pracujących na uniwersytecie.

(Stiegler: 88)

Winą za tę sytuację obarcza Stiegler fundamentalne zapomnienie, które objęło formacyjne (w znaczeniu Bildung), polityczne i gospodarcze założenia Kantowskiej Aufklärung; konstrukcji zbudowanej na takich „konceptach jak podmiot, rozum, prawda, odpowiedzialność, suwerenność". W końcu i sama głupota oraz wiedza jako swoista kontrasygnata głupoty uległy zapomnieniu (Stiegler: 89).

Do rangi symbolu intelektualnej zdrady niewątpliwie należy przypadek Martina Heideggera, który związał się na pewien czas z ruchem narodowosocjalistycznym w Niemczech. Autor Bycia i czasu, wyrafinowany intelektualista, wpływowy uczony, którego dzieła były dla wielu inspiracją, dopuścił się w latach trzydziestych ubiegłego stulecia wielu nikczemnych czynów: donosił na swoich żydowskich przyjaciół, jawnie popierał Hitlera, po wojnie zaś zachowywał niezrozumiałe milczenie na temat tego faszystowskiego epizodu. W Lekkomyślnym umyśle Mark Lilla przytacza symptomatyczną i emblematyczną historię. Oto krótko po wojnie pewien znajomy Martina Heideggera podczas spotkania ze swoim dawnym mistrzem skierował do fryburskiego filozofa ironiczne pytanie: „Powrót z Syrakuz?”. „Trudno o lepszy bon mot” (Lilla: 159), powiada Lilla. Oto Heidegger, niczym Platon, doświadczył osobistej klęski, wierząc, że może wpłynąć na postępowanie tyrana. Przypadek Platona - o czym możemy przeczytać w jego Liście siódmym - polegał na tym, że grecki filozof marzył ongiś, że uda mu się tak zaangażować w politykę, aby „wychować” i „nawrócić” tyrana. Platon zaprzyjaźniony z arystokratą Dionem udał się niegdyś na Sycylię, gdzie po śmierci Dionizjosa Starszego rządy objął Dionizjos Młodszy. Wedle Diona, szwagra Dionizjosa, młody władca wykazywał wielkie zainteresowanie filozofią 
i zapragnął być sprawiedliwy. Po pewnym czasie powziął jednak podejrzenie, że Dion pragnie obalić jego panowanie. Wyprawa Platona zakończyła się niepowodzeniem. Po jego wyjeździe Dion zaatakował Syrakuzy i wypędził Dionizjosa, potem zaś Dionizjos odzyskał tron, doprowadzając uprzednio do śmierci Diona, po czym założył w Koryncie szkołę filozoficzną, gdzie ponoć wykładał. „Dionizjos - pisze Mark Lilla - jest naszym współczesnym. W przeciągu ostatniego stulecia przyjmował rozmaite imiona: Lenina i Stalina, Hitlera i Mussoliniego, Mao i Ho, Castro i Trujillo, Amina i Bokassy, Saddama i Chomejniego, Ceauçescu i Milošewicia” (Lilla: 161). Wiara (?) Heideggera w misję odnowicielską Hitlera należy do tej właśnie - starej jak świat - historii. Jak to się jednak stało, że myśliciel tej rangi co autor Bycia i czasu, ów niedoszły jezuita, uwierzył niemieckiemu tyranowi? Spośród wielu możliwych odpowiedzi najbardziej złowroga jest ta, która źródła Heideggerowskiej fascynacji Hitlerem wywodzi wprost z idei, które głosił fryburski filozof, a także - o czym wielokroć wspominała Hanna Arendt - z namiętności do myślenia oraz pragnienia władzy, potrzeby wpływania na bieg zdarzeń (Ott, 2013). Afektywny urok Syrakuz na zawsze już pozostanie znakiem „pokusy”, której ulec może każdy, najwybitniejszy nawet intelektualista: namiętności do wiedzy, która staje się władzą.

Określenie intelektualisty jako upadłego proroka nie musi jednak być figurą klęski autorytetu i rezultatem poznawczego impasu. Rozpad ethosu naukowca (człowieka uniwersytetu) może bowiem stać się impulsem do uświadomienia sobie, że kolizja dogmatycznego scjentyzmu i relatywistycznego empiryzmu prowadzi do uznania oczywistego, bądź co bądź, faktu, że - jak twierdzi Leszek Kołakowski - „naszą kulturę utrzymuje przy życiu raczej konflikt wartości niż ich harmonia” (Kołakowski, 2003: 89), zaś „poszukiwanie pewności” jako efekt „pragnienia życia w świecie, z którego przypadkowość jest wygnana” zawsze będzie motorem działań naukowych, z tym wszelako zastrzeżeniem, że „nauka nie jest zdolna dać nam tego rodzaju pewności” (Kołakowski: 88).

\section{Bibliografia}

Adorno, Theodor W., Max Horkheimer. Dialektyka oświecenia. Fragmenty filozoficzne. Tłum. Małgorzata Łukasiewicz, przekład przejrzał i posłowiem opatrzył Marek Siemek. Warszawa: Wydawnictwo Krytyki Politycznej, 2010. 
Bauman, Zygmunt. Prawodawcy i ttumacze. Warszawa: Wydawnictwo IFiS PAN, 1998.

-----. Socjalizm. Utopia w dziataniu. Tłum. Michał Bogdan. Warszawa: Wydawnictwo Krytyki Politycznej, 2010.

Benda, Julien. Zdrada klerków. Tłum. Marek J. Mosakowski. Warszawa: Wydawnictwo Krytyki Politycznej, 2014.

Burke, Peter. Spoteczna historia wiedzy. Tłum. Anna Kunicka. Warszawa: Wydawnictwo Aletheia, 2016.

Furedi, Frank. Gdzie się podziali wszyscy intelektualiści? Tłum. Katarzyna Makaruk. Warszawa: Państwowy Instytut Wydawniczy, 2014.

Hegel, Georg Wilhelm Friedrich. Fenomenologia ducha. Tłum. ŚwiatosławFlorian Nowicki. Warszawa: Fundacja Aletheia, 2002.

Kołakowski, Leszek. Husserl i poszukiwanie pewności. Tłum. Piotr Marciszuk. Kraków: Znak, 2003.

Lilla, Mark.. Lekkomyślny umyst. Intelektualiści w polityce. Tłum. Janusz Margański. Warszawa: Wydawnictwo Prószyński i S-ka, 2007.

Lyotard, Jean- François. Kondycja ponowoczesna. Raport o stanie wiedzy. Tłum. Małgorzata Kowalska, Jacek Migasiński. Warszawa: Fundacja Aletheia, 1997.

Ott, Hugo. Martin Heidegger. W drodze do biografii. Tłum. Janusz Sidorek. Warszawa: Wydawnictwo Aletheia, 2013.

Perelman, Chaïm. Imperium retoryki. Retoryka i argumentacja. Tłum. Mieczysław Chomicz. Red. Ryszard Kleszcz. Warszawa: Wydawnictwo Naukowe PWN, 2002.

Rusinek, Michał. Między retoryką a retorycznością. Kraków: Universitas, 2003.

Scruton, Roger. Gtupcy, oszuści i podżegacze. Myśliciele nowej lewicy. Tłum. Filip Filipowski. Poznań: Wydawnictwo Zysk i S-ka, 2018.

-----. Przewodnik po kulturze nowoczesnej dla inteligentnych. Tłum. Jerzy Prokopiuk, Jan Przybył. Łódź-Wrocław: Wydawnictwo Thesaurus, 2006.

Simmel, Georg. Filozofia pieniądza. Tłum. Andrzej Przyłębski. Warszawa: Wydawnictwo Aletheia, 2012.

Somwell, Thomas. Intelektualiści mądrzy i niemądrzy. Tłum. Kamil Maksymiuk-Salamoński. Warszawa: Fijor Publishing Company, 2010.

Stiegler, Bernard. Wstrzasy. Gtupota i wiedza w XXI wieku. Tłum. Michał Krzykawski. Warszawa: Wydawnictwo Naukowe PWN, 2017. 


\title{
An Intellectual as a Fallen Prophet. The Discreet, Rhetorical Charm of Syracuse
}

\begin{abstract}
Summary
The article makes an attempt at describing the socio-symbolic field in which the contemporary intellectual has to act. The intellectual has undergone the processes of his/her position and his/her role in academic (intellectual) life, which is one of the reasons of the failure of thinking (reason). The article also encompasses an attempt at answering the following questions: what is the role of the three basic components of classical rhetoric: logos, ethos and pathos, in thinking? Why has the contemporary homo academicus ceased to be a guide and a translator? What is the influence of affections on thinking and where did all the intellectuals go? (Frank Furedi). What is the relation between knowledge, affections, and power, and stupidity?
\end{abstract}

Keywords: intellectualist, thinking, mind, captive mind, rhetoric, affects

Słowa kluczowe: intelektualista, myślenie, rozum, zniewolony umysł, retoryka, afekty 